\title{
First record of teak leaf rust (Olivea tectonae) in Australia
}

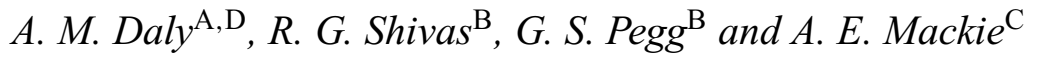 \\ ${ }^{A}$ Department of Primary Industry, Fisheries and Mines, Diagnostic Services Division, GPO Box 3000, Darwin, \\ NT 0801, Australia. \\ ${ }^{B}$ Department of Primary Industries and Fisheries, 80 Meiers Road, Indooroopilly, Qld 4068, Australia. \\ ${ }^{\mathrm{C}}$ Department of Agriculture and Food Western Australia, Locked Bag 4, Bentley Delivery Centre, WA 6983, Australia. \\ ${ }^{\mathrm{D}}$ Corresponding author. Email: andrew.daly@nt.gov.au
}

Abstract. Teak leaf rust, caused by the fungal pathogen Olivea tectonae, was first discovered in Australia in June 2006.

The rust was found in the Northern Territory, Queensland and Western Australia.

Teak (Tectona grandis L.f.) is endemic to India and IndoChina and has been grown in the Northern Territory on a small scale for 20 years. Most plantings that currently exist in the Northern Territory are either for demonstration or assessment of commercial viability. There are also small areas planted in northern Queensland and Western Australia. In Western Australia, teak is mainly planted as a host of sandalwood.

Teak leaf rust, caused by Olivea tectonae (T.S. Ramakr. \& K. Ramakr.) Thirum. was found near Darwin in an irrigated commercial planting of 300 trees of 2-3 years of age in June 2006. Within a month it had also been detected in northern Western Australia and northern Queensland. Teak leaf rust had not been previously recorded in Australia although it has been known to occur in Java, Indonesia for over 100 years (Raciborski 1900). Voucher specimens were deposited in the Plant Pathology Herbarium (BRIP), Queensland Department of Primary Industries and Fisheries, Indooroopilly.

Infected leaves had small angular brown to grey necrotic areas on the upper leaf surfaces. Large areas of necrosis were evident where lesions had coalesced. The necrotic areas corresponded to numerous subepidermally erumpent uredinia on the lower leaf surfaces (Fig. 1). Uredinia were paraphysate at the margin with cylindrical, incurved uredinial paraphyses measuring $30-45 \times 10-17 \mu \mathrm{m}$ with hyaline to pale brown, smooth walls up to $3 \mu \mathrm{m}$ thick at the sides and $5 \mu \mathrm{m}$ at the apex (Fig. 2). Urediniospores were produced singly on a short pedicel, subglobose, ovoid to ellipsoid, mostly hyaline, occasionally pale brown, measuring $18-26 \times 16-21 \mu \mathrm{m}$, echinulate with spines $\sim 2 \mu \mathrm{m}$ apart; germ pores were not seen (Fig. 3). Teliospores were not observed. This agrees with the description given by Mulder and Gibson (1973). In Australia, O. tectonae has been found at Howard Springs (BRIP 48158), Berrimah (BRIP 48159) and in the Douglas Daly region $\sim 160 \mathrm{~km}$ south of Darwin (BRIP 48160) in the Northern Territory; at Murray Upper (BRIP 48198) and Mt Ray (BRIP 48180) in Queensland; and at Kununurra (BRIP 48266) in Western Australia.

Teak typically becomes dormant and loses its leaves during the dry season (May to October) in the northern region of Australia but some plantings that are irrigated maintain foliage for their entire productive life. This may mean that $O$. tectonae is capable of existing indefinitely in an irrigated planting as urediniospores, the only spore type known to occur in Australia. In addition, there are over 50 species of Verbenaceae (native and introduced) occurring in the Northern Territory (Dunlop et al. 1996) and it is not known

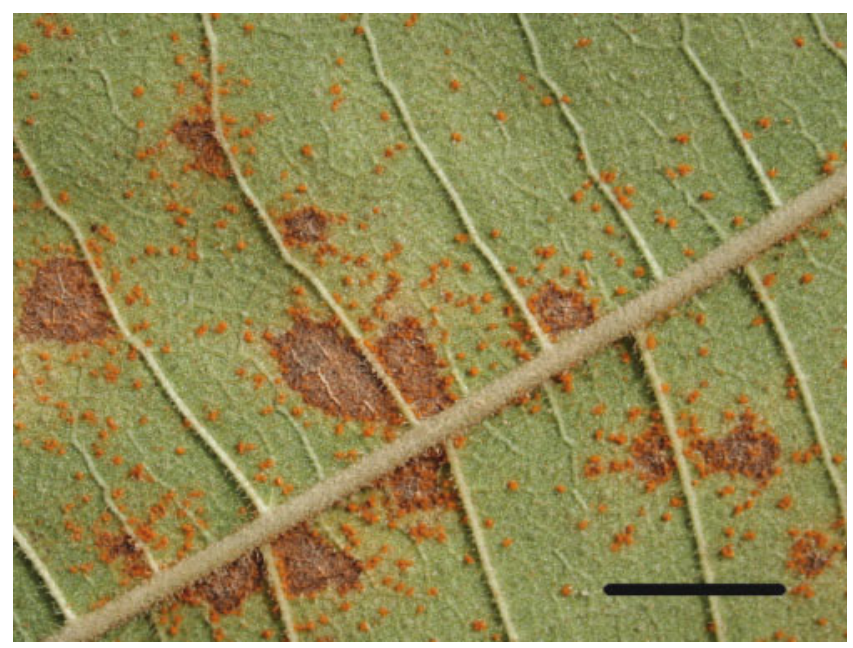

Fig. 1. Uredinia of Olivea tectonae on the lower leaf surface of Tectona grandis $(\mathrm{bar}=10 \mathrm{~mm})$. 


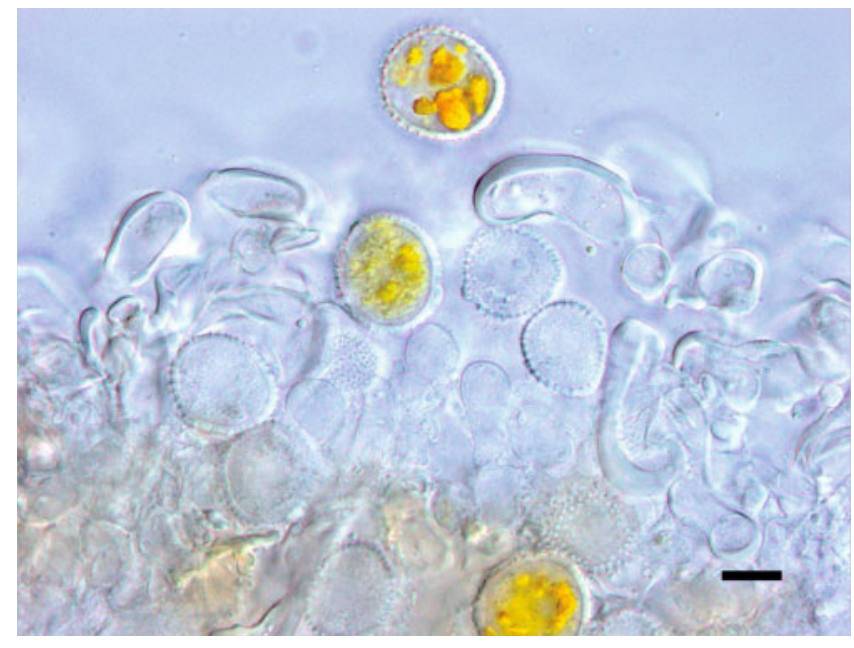

Fig. 2. Urediniospores and uredinial paraphyses (bar $=10 \mu \mathrm{m})$.

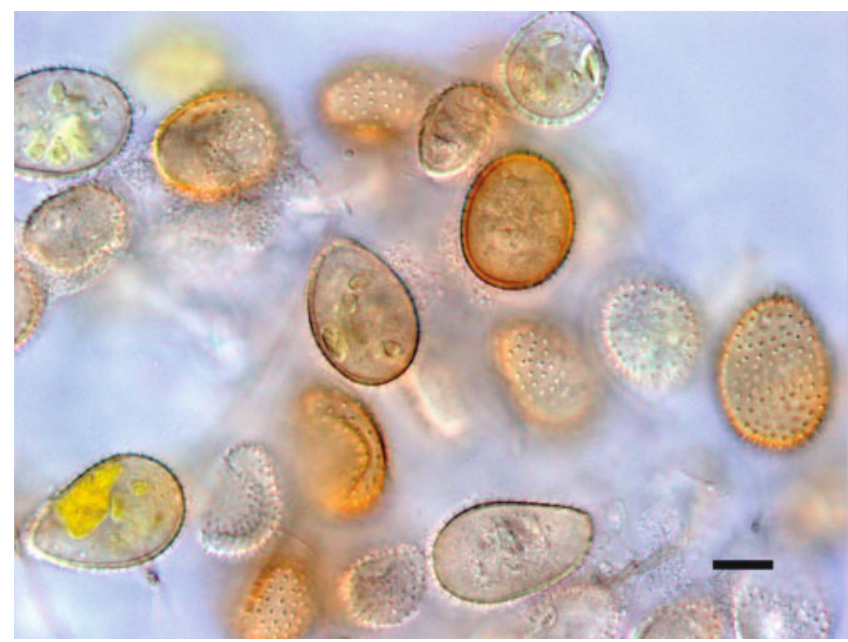

Fig. 3. Urediniospores of Olivea tectonae (bar $=10 \mu \mathrm{m})$.
O. tectonae has been reported from many parts of South, East and South-East Asia. In South-East Asia, it is considered to be a serious pathogen of young seedlings, a minor pathogen of seedlings older than two months and of no concern in mature plantation trees (Su-See 1999). Disease control is achieved by the use of fungicides in nursery situations and pruning and thinning to encourage better ventilation in young plantations. In Australia, O. tectonae is unlikely to have any serious effect on teak production.

It is not known how the pathogen entered Australia. Trees that have been planted in Australia originated either via seeds or disease-free tissue cultured plantlets imported under quarantine conditions or by seed from existing plants. It is possible the pathogen arrived from South East-Asia as windborne spores carried by the monsoonal weather system.

\section{Acknowledgements}

We thank Don Reilly (Department of Primary Industry, Fisheries and Mines) for collecting specimens and providing information about the teak industry in the Northern Territory, and Tracy Vinnicombe (Department of Agriculture and Food Western Australia) for collecting specimens from Kununurra.

\section{References}

Dunlop CR, Leach GJ, Albrecht DE, Barritt MJ, Cowie ID, Latz PK (1996) 'Checklist of the Vascular Plants of the Northern Territory, Australia.' (Parks and Wildlife Commission of the Northern Territory: Palmerston)

Mulder JL, Gibson IAS (1973) 'Olivea tectonae. CMI Descriptions of Pathogenic Fungi and Bacteria, No. 365.' (Commonwealth Mycological Institute: Kew)

Raciborski M (1900) 'Parasitische Algan und Pilze Java's. Part 1.' (J. Cramer: Lehre)

Su-See L (1999) Forest health in plantation forests in South-East Asia. Australasian Plant Pathology 28, 283-291. doi: 10.1071/AP99045

if any of these plants are an alternative host of the pathogen. Another species of teak (Tectona hamiltoniana), native to Burma, is also grown in the Northern Territory.
Received 12 September 2006, accepted 27 September 2006 